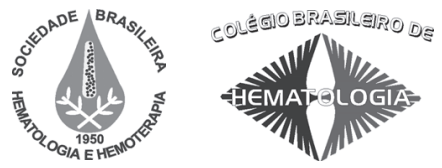

\title{
Determination of iron-overload in thalassemia by hepatic MRI and ferritin
}

\section{Determinação da sobrecarga de ferro na talassemia pela IRM hepática e ferritina}

Ivan L. Angulo ${ }^{1}$

Dimas T. Covas ${ }^{2}$

Antonio A. Carneiro ${ }^{3}$

Oswaldo Baffa ${ }^{4}$

Jorge Elias Junior ${ }^{5}$

Guilherme Vilela ${ }^{6}$

\begin{abstract}
Accumulation of iron in thalassemia causes organ damage and reduces patient survival due to heart lesions in the second decade of life. Iron deposits are monitored by direct (biopsy) and indirect methods (ferritin) with sequential data being better than isolated measurements. This paper compares two indirect measurements of iron overload; a single hepatic iron concentration (HIC) by magnetic resonance and mean ferritin levels over four years. A retrospective study of 25 patients from the Centro Regional de Hemoterapia in Ribeirão Preto, Brazil was carried out. High HIC (above $7 \mathrm{mg}$ per gram of dry weight) was found in 20 patients and high mean serum ferritin (above $2500 \mu \mathrm{g} / \mathrm{L}$ ) in 10 patients. Stratification into three levels (low, moderate and high) of iron overload gave similar results in both tests. Many other factors influence de degree of iron overload in thalassemia. No correlation was found using a non-parametric statistical test between HIC and mean serum ferritin. Both methods provide better planning of chelation therapy. Rev. Bras. Hematol. Hemoter. 2008;30(6):449-452.
\end{abstract}

Key words: Iron overload; thalassemia; magnetic resonance imaging; ferritin; chelation.

\section{Introduction}

The accumulation of iron in thalassemia causes organic injuries and a reduction in survival and must be treated with iron chelators such as deferoxamine. The success of treatment depends essentially on patient adherence and can be evaluated by determining iron loading by direct or indirect methods. The accumulation of transfusional and absorbed iron in thalassemia is approximately 7 to 14 grams per year. The measurement of iron is important for the prognosis (risk of organic and associated injuries) and monitoring chelation. ${ }^{1,2}$

Ferritin is the principal iron storage protein, found in the liver, spleen, bone marrow, and to a small extent in the blood (serum ferritin - SF). ${ }^{3}$ In the majority of clinical centers, the standard method of evaluating the total amount of body iron is measurement of the SF concentration in the blood. ${ }^{4}$ However, the correlation between SF and body iron is not sufficiently precise to be of high prognostic value, especially when associated with inflammation or tissue damage. Moreover, alterations in the relationship between blood serum ferritin concentration and body iron content by chelation and vitamin $\mathrm{C}$ treatment are complex. For example, the relationship between serum ferritin and body iron appears to be singular for different hematologic conditions. ${ }^{5}$ SF has been the primary clinical measure of iron stores in thalassemic patients undergoing transfusions. It is non-invasive, widely available, inexpensive, but has not been systematically compared to validated quantitative measurements of liver iron using techniques such as MRI. ${ }^{6}$

${ }^{1}$ Médico do Centro Regional de Hemoterapia do Hospital das Clínicas da Faculdade de Medicina de Ribeirão Preto - USP-SP.

${ }^{2}$ Diretor-presidente da Fundação Hemocentro de Ribeirão Preto, docente do Departamento de Clínica Médica da Faculdade de Medicina de Ribeirão Preto - USP-SP.

${ }^{3}$ Professor da Faculdade de Filosofia, Ciências e Letras de Ribeirão Preto - USP-SP.

${ }^{4}$ Professor Titular da Faculdade de Filosofia, Ciências e Letras de Ribeirão Preto - USP-SP.

${ }^{5}$ Professor do Departamento de Clínica Médica, Faculdade de Medicina de Ribeirão Preto - USP-SP.

${ }^{6}$ Aluno da FFCLRP.

Fundação Hemocentro de Ribeirão Preto - SP.

Correspondência: Ivan de Lucena Angulo

Rua Ten. Catão Roxo, 2501

14051-140 - Ribeirão Preto-SP - Brasil

Email:angulo@pegasus.fmrp.usp.br 
The liver is the main iron storage organ in the body, containing approximately $70 \%$ of the total content of the body. Liver iron can be assessed by needle biopsy or, more recently, by noninvasive magnetic resonance imaging (MRI). As liver iron correlates with total body iron, an alternative to evaluating body iron overload is the measurement of liver iron concentration (LIC). Thus, liver iron concentration (LIC) gives a measure of parenchymal and macrophage iron stored in Kupfer cells. Direct methods, such as hepatic biopsy and susceptometry, are not influenced by other factors, but are difficult to achieve, due to their invasiveness and high cost and because the equipment is generally unavailable. ${ }^{6}$

Amongst the indirect methods, measurement of the amount of liver iron by MRI is the best, because of its advantage of not being invasive and also because it allows an anatomical view of iron overload in the liver. This method enables measurement of iron in milligrams per gram of tissue, and estimates of the risk of organic diseases. ${ }^{7}$ SF has been compared with liver iron in transfused thalassemia major patients and demonstrated a good correlation, but a wide prediction range reduces its clinical utility. Despite the limitations of isolated SF and LIC comparisons, SF followed over time, as a trend or as a mean, has been a reasonable predictor of clinical outcome. ${ }^{8}$

The clinical consequences of iron overload are varied and reflect the key sites of iron storage. In the liver, the formation of collagen and portal fibrosis have been shown to occur after about two years of transfusion therapy. Iron accumulation in the heart is the leading cause of death in patients with thalassemia major. Endocrine glands are also affected. Patient compliance with treatment regimens and effective chelation therapy are thought to be the main factors associated with improved survival. ${ }^{4,7}$ Patients with serum ferritin persistently above $2500 \mu \mathrm{g} / \mathrm{L}$ have a greater risk of cardiac injury, but interference of other biological factors exists, turning this into an inexact evaluation ${ }^{4}$ with some authors preferring a value of $1500 \mu \mathrm{g} / \mathrm{L} .{ }^{8}$ Measurements of LIC above $1.6 \mathrm{mg} / \mathrm{g}$ of dry weight $(\mathrm{mg} / \mathrm{gdw})$ are considered high, there is a small risk of complications when under $7 \mathrm{mg} /$ gdw, between 7 and $15 \mathrm{mg} / \mathrm{gdw}$ are intermediate values and patients with above $15 \mathrm{mg} / \mathrm{gdw}$ have a risk of serious injury, including fibrosis and cirrhosis of the liver, and cardiac death. ${ }^{3,7}$ Infection by Hepatitis C Virus (HCV) with inflammation does not affect the MRI measurements, but may affect ferritin. ${ }^{8}$

As the accumulation of iron in the myocardium seems to be associated with arrhythmias and organ insufficiency, the measurement of cardiac iron is also important, but is calculated using a different technique. ${ }^{9}$

The main objective of this paper is to quantify liver iron concentration (LIC) by magnetic resonance in multitransfused thalassemia patients chelated with deferoxamine and compare this to mean ferritin values over a four-year period as well as classify patients for risk of illness and death.

\section{Patients and Method}

A retrospective study in a group of thalassemia major and intermediate patients, followed at the Centro Regional de Hematologia e Hemoterapia (Regional Blood Center) of Ribeirao Preto Hospital and Clinics-HCRP, (Hospital das Clínicas of the Medicine School in Ribeirão Preto) was performed, in which 43 magnetic resonance investigations were carried out for the quantification of LIC. Evaluations were carried out in the Radiology Department of HCRP and in the Physics and Mathematics Department, University of Philosophy, Sciences and Languages of Ribeirão Preto, University of São Paulo, campus of Ribeirão Preto, Brazil. To evaluate liver iron overload, MR images were acquired using two SE and two GRE sequences on a 1.5-T whole body scanner (Siemens Magneton Vision Plus). LIC values from relaxometry $(R 2)$ using SSE sequences were computed according to the protocol developed by Clark and St. Pierre, ${ }^{10,11}$ who validated their protocol of quantifying iron overload from $R 2$ using more than 100 biopsies.

Twenty-five patients including 11 women with an average age of $21 \pm 7$ years old (range: 6 to 39 ) were evaluated. They had been multitransfused since infancy, were under chelation with deferoxamine with good adherence to treatment and had a yearly blood consumption below $200 \mathrm{~mL}$ per kilogram. The LIC was quantified, as described, in milligrams per gram of dry weight $(\mathrm{mg} / \mathrm{gdw})$ of liver with normal values being under $1.6 \mathrm{mg} / \mathrm{gdw} .10,11$

The serum ferritin was assessed by chemoluminescence and an average of 15 measurements per patient were performed over a four-year period. Normal values are $300 \mu \mathrm{g} / \mathrm{L}$ for men and $150 \mu \mathrm{g} / \mathrm{L}$ for women.

The data was analyzed using the Spearman correlation by the Instat program version 3.01 (GraphPad Software, Inc.) with values under 0.05 being considered significant.

\section{Results}

The average serum ferritin level was $2,337 \pm 1,012 \mu \mathrm{g} / \mathrm{L}$ (range: 481-7595). In 4/25 patients mean SF measurements were under $1500 \mu \mathrm{g} / \mathrm{L}$ (low risk of complications), in 11/25 patients between $1500 \mu \mathrm{g} / \mathrm{L}$ and $2500 \mu \mathrm{g} / \mathrm{L}$ (intermediate risk), and in $10 / 25$ above $2500 \mu \mathrm{g} / \mathrm{L}$ (high risk). An average LIC of $14.16 \pm 8.09$ (range: $3.3-36.3$ ) $\mathrm{mg} / \mathrm{gdw}$ was found. In $5 / 25$ patients values were under $7 \mathrm{mg} / \mathrm{gdw}$ (low risk of complications), in $11 / 25$ between 7 and $15 \mathrm{mg} / \mathrm{gdw}$ (intermediate risk), and in 9/ 25 the concentration was above $15 \mathrm{mg} / \mathrm{gdw}$ (high risk).

Injuries from iron accumulation were found in 19/25 patients and were mainly heart related (arrhythmia or insufficiency) in three, diabetes mellitus in one, growth retardation in four and hypogonadism in eleven patients. In 12/25 there were antibodies against Hepatitis C Virus (ab anti-HCV). In only $11 / 25$ patients there was concordance between SF and LIC for risk of organ disease. 


\begin{tabular}{|c|c|c|c|c|}
\hline age, gender & $\begin{array}{c}\text { Mean } \\
\text { ferritin } g / L\end{array}$ & LIC mg/gdw & Risk ferritin & Risk LIC \\
\hline $\mathrm{M}, 17$ & 1816 & 16 & Intermediate & High \\
\hline$F, 23$ & 1719 & 8,4 & Intermediate & Intermediate \\
\hline M, 6 & 2092 & 16,7 & Intermediate & High \\
\hline$F, 23$ & 1816 & 13 & Intermediate & Intermediate \\
\hline $\mathrm{M}, 14$ & 1955 & 11,2 & Intermediate & Intermediate \\
\hline M, 24 & 3690 & 28,2 & High & High \\
\hline$F, 18$ & 1949 & 6 & Intermediate & Low \\
\hline$M, 24$ & 1312 & 19,9 & Low & High \\
\hline$F, 18$ & 2781 & 12 & High & Intermediate \\
\hline$M, 14$ & 2538 & 14,1 & High & Intermediate \\
\hline $\mathrm{M}, 19$ & 2597 & 13,1 & High & Intermediate \\
\hline M, 25 & 1640 & 4,3 & Intermediate & Low \\
\hline$M, 16$ & 1370 & 19,9 & Low & High \\
\hline M, 19 & 2065 & 9,3 & Intermediate & Intermediate \\
\hline $\mathrm{F}, 20$ & 2215 & 4,3 & Intermediate & Low \\
\hline$F, 22$ & 2756 & 19,5 & High & High \\
\hline$M, 27$ & 4930 & 119,9 & High & Intermediate \\
\hline $\mathrm{F}, 18$ & 2884 & 9,2 & High & Intermediate \\
\hline$M, 23$ & 1622 & 14,5 & Intermediate & Intermediate \\
\hline M, 28 & 2767 & 36,3 & High & High \\
\hline$M, 20$ & 4931 & 21,5 & High & High \\
\hline$F, 11$ & 1852 & 26,5 & Intermediate & High \\
\hline$F, 26$ & 3007 & 8,6 & Hlgh & Intermediate \\
\hline$F, 35$ & 905 & 3,3 & Low & Low \\
\hline$F, 39$ & 1215 & 6,4 & Low & Low \\
\hline
\end{tabular}

$\mathrm{M}=$ male $(14), \mathrm{F}=$ female $(11)$

No correlation was found between mean ferritin and LIC using the Spearman test, $(r=0.2655,95 \%$ CI -0.1570 to $0.6059, \mathrm{p}=0.1995$ - not significant). Table 1 shows risk classification and the results of the LIC and mean ferritin levels of the patients.

\section{Discussion}

The validation of a method of iron measurement in multitransfused patients is essential to optimize therapeutic chelation, controlling iron loading and avoiding chelator toxicity. Traditionally it is achieved using serum ferritin with known limitations. ${ }^{12}$ Magnetic resonance imaging seems to be a better method. It is less invasive than liver biopsy and is not affected by interference from fibrosis. ${ }^{8}$ Cardiac injury was responsible for death of $70 \%$ of the patients in the past but thanks to aggressive chelation, this rate has dropped to between 50 to $67 \%$ and, in particular, increased the survival of women, even though clearance of myocardial iron is slower than hepatic deposits. Currently, $5 \%$ of the patients present cardiac injury, such as arrhythmias or organ insufficiency. ${ }^{13-16}$

The results presented here are of a group of young patients, transfused since infancy and with good adherence to chelation using deferoxamine. The majority already have endocrine gland lesions due to iron accumulation. There was concordance of risk as estimated by LIC and mean ferritin levels in only 11 individuals, but overall results were very similar. High risk was identified in 10/25 using serial ferritin measurements and in $9 / 25$ patients by LIC. These patients need aggressive chelation therapy immediately. Thus the estimate of the accumulation of liver, and thus body, iron by magnetic resonance did not identify more at-risk patients than the mean SF levels, but only one measurement was required. LIC needs to be performed periodically, for example, once a year, and at shorter intervals for intensively cheated patients. SF must be measured at least 3 times a year. Measurement of liver iron allows real quantification of iron accumulation, the effectiveness of chelation and enables changes in strategy ${ }^{17}$ at a glance. This requires much time with SF. There are many other factors that influence iron loading and organ disease in thalassemia and treatment must be individualized. Perhaps the best strategy would be to use both techniques, mean SF and LIC by MRI, frequently. But MRI is not as accessible as SF. Machines are expensive and busy in public hospitals. We suggest that, for thalassemia patients undertaking blood transfusion, the mean SF should be kept under $1500 \mathrm{mg} / \mathrm{L}$ by chelation if possible and organ function should be monitored closely. A LIC evaluation performed once per year is an additional tool to monitor iron accumulation however prognosis must not be based on an isolated measurement.

\section{Resumo}

O acúmulo de ferro na talassemia causa lesões orgânicas e reduz a sobrevida do paciente por lesão cardíaca na segunda década da vida, e tem sido avaliado por medidas diretas (biópsia) e indiretas (ferritina). As medidas isoladas carecem de valor, sendo preferidas as sequenciais. Este trabalho pretende comparar medidas indiretas de sobrecarga de ferro, uma medida da concentração de ferro hepático por ressonância magnética, e a ferritina sérica média dos últimos quatro anos. Trata-se de estudo retrospectivo de 25 pacientes do Centro Regional de Hemoterapia, em Ribeirão Preto, Brasil. Encontrou-se em vinte pacientes ferro hepático acima de $7 \mathrm{mg} / \mathrm{g}$ peso seco e ferritina média elevada acima de $2.500 \mathrm{ug} / \mathrm{l} \mathrm{em} \mathrm{dez.}$ Estratificação em três níveis de sobrecarga (leve, moderada e grave) produziu resultados semelhantes em ambos os testes. Vários outros fatores influenciam o grau de sobrecarga de ferro na talassemia. Não houve correlação significativa com aplicação de testes não-paramétricos. Ambos os métodos usados concomitan- 
temente levarão a um melhor planejamento da terapia quelante. Rev. Bras. Hematol. Hemoter. 2008;30(6):449-452.

Palavras-chave: Sobrecarga de ferro; talassemias; imagens de ressonância magnética; ferritina; quelação.

\section{Acknowledgments}

Fapesp, CNPq, Capes and Fundação Hemocentro for partial financial support.

\section{References}

1. Olivieri NF. The beta Thalassemias. N Engl J Med. 1999;341(2): 99-109.

2. Old JM, Olivieri NF. Management and prognosis. In: Weatherall DJ, Clegg JB, editors. The Thalassaemia Syndromes. Oxford: Blackwell Science; 2001. p. 630.

3. Torti FM, Torti SV. Regulation of ferritin genes and protein. Blood. 2002;99(10):3505-16.

4. Olivieri NF, Brittenham GM. Iron-chelating therapy and the treatment of Thalassemia. Blood. 1997;89(3):739-61.

5. Brittenham GM, Cohen AR, McLaren CE, Martin MB, Griffith PM, Nienhuis AW et al. Hepatic iron stores and plasma ferritin concentration in patients with sickle cell anemia and thalassemia major. Am J Hematol. 1993;42(1):81-5.

6. Angelucci E, Giovagnoni A, Valeri G, Paci E, Ripalti M, Muretto P, et al. Limitations of magnetic resonance imaging in measurement of hepatic iron. Blood. 1997;90(12):4736-42.

7. Taher A, Nathan D, Porter JD. Evaluation of Iron Levels to Avoid the Clinical Sequelae of Iron overload. Semin Hematol. 2007;44, Sup 3: S2-S6

8. Telfer PT, Prestcott E, Holden S, Walker M, Hoffbrand AV, Wonke B. Hepatic iron concentration combined with long-term monitoring of serum ferritin to predict complications of iron overload in thalassaemia major. Br J Haematol. 2000;110(4):971-7.
9. Westwood MA, Sheppard MN, Awogbade M, Ellis G, Stephens AD, Pennell DJ. Myocardial biopsy and T2* magnetic resonance in heart failure due to thalassaemia. Br J Haematol. 2005;128(1):2.

10. St Pierre TG, Clark PR, Chua-anusorn W, Fleming AJ, Jeffrey GP, Olynyk JK et al. Noninvasive measurement and imaging of liver iron concentrations using proton magnetic resonance. Blood. 2005; 105(2):855-61.

11. Carneiro AA, Fernandes JP, de Araujo DB, Elias J Jr, Martinelli AL, Covas DT et al. Liver iron concentration evaluated by two magnetic methods: magnetic resonance imaging and magnetic susceptometry. Magn Reson Med. 2005;54(1):122-8.

12. Jensen PD. Evaluation of iron overload. Br J Haematol. 2004; 124(6):697-711.

13. Pennell DJ. Iron Overload and the Heart. 2004; Hematology Education Program Book. American Society of Hematology. P. 20-25.

14. Schrier SL, Angelucci E. New strategies in the treatment of the thalassemias. Annu Rev Med. 2005;56:157-71.

15. Borgna-Pignatti C, Rugolotto S, De Stefano P, Zhao H, Cappellini MD, Del Vecchio GC et al. Survival and complications in patients with thalassemia major treated with transfusion and deferoxamine. Haematologica. 2004;89(10):1187-93.

16. Cunningham MJ, Macklin EA, Neufeld EJ, Cohen AR. Complications of beta-thalassemia major in North America. Blood. 2004;104 (1):34-9.

17. Hershko C, Cappellini MD, Galanello R, Piga A, Tognoni G, Masera G. Purging iron from the heart. Br J Haematol. 2004;125(5):545-51.

Avaliação: Editor e dois revisores externos Conflito de interesse: não declarado

Recebido: 08/04/2008

Aceito após modificações: 30/09/2008 